\author{
Piotr Szczekocki \\ Maria Curie-Skłodowska University in Lublin, Poland \\ ORCID: 0000-0001-5756-3611 \\ piotrszczekocki@op.pl
}

\title{
Axiology of Judicial Application of Enforcement Law: View on the Bailiff's Discretion
}

\author{
Aksjologia sądowego stosowania prawa egzekucyjnego: \\ punkt widzenia dyskrecjonalności komornika
}

\section{SUMMARY}

In the article, the author focused on three theoretical and philosophical issues of the judicial enforcement law in Poland, connected with the new enforcement acts which entered into force on 1 January 2019. First, the judicial enforcement proceedings were presented as an element of the law application process. The axiological dimension of this law, the place and function of a court bailiff in the law application process and the introduction of general clauses, combined with the basic values of the court enforcement law in the form of efficiency, effectiveness and reliability, form the new picture of the judicial enforcement law. Secondly, the problem of a general clause as a "carrier" of extralegal criteria was discussed, which takes an important place in the process of enforcement law application in the new bailiff's law. There is the special role of the "public interest" and the "interest of justice" clauses as normative constructions introduced by the legislator to judicial enforcement. Thirdly, an attempt was made to answer the question about the presence and possible limits of discretion (free decision-making) of a court bailiff in the surrounding of the new axiology of enforcement law, and especially the formulation of this issue in the process of operative interpretation of law by a court bailiff.

Keywords: law axiology; judicial enforcement law; law application process; general clause; public interest; interest of justice; bailiff's discretion

\section{INTRODUCTION}

The following paper attempts to present the axiological determinants of enforcement proceedings as a specific kind of the decision-making process in which the sphere of assessments and values contributes to the law axiology issues in 
general and provides an important source for building the legal order, especially for shaping the enforcement law system in the legal practice.

In Poland, the philosophical aspects of judicial enforcement law have been overlooked both in the legal doctrine and in the relevant court decisions so far. Nevertheless, in enforcement proceedings these issues are the focus of enforcement law axiology, especially values and goals pursued in these proceedings. The actions of institutions applying enforcement law (bailiffs) are directed at implementation of a number of these values. Assuming that court enforcement bodies are functioning within the broadly understood process of law application and that the actions undertaken by them have a decision-making value (of varying degrees), while the enforcement law sources are not free from gaps and extralegal structures (general clause), such an approach poses an additional question about the discretion of these bodies in the aspect of their decision-making freedom and its limitations.

\section{JUDICIAL ENFORCEMENT PROCEEDINGS OF APPLICATION LAW. THEORETICAL PERSPECTIVE}

Polish enforcement law can be analyzed as two different types: judicial enforcement law and administrative enforcement law. Such division is justified by the existence of two types of law application ${ }^{1}$ : judicial and non-judicial (which mostly relates to administrative issues) ${ }^{2}$. Administrative enforcement law concerns the cases with a state body like a tax office or the Social Security Institution involved ${ }^{3}$. In judicial enforcement law, both parties are usually private, and the main role here is the obligatory enforcement of civil law norms ${ }^{4}$.

A bailiff is a Polish public officer serving as an executive body in judicial enforcement law. A Polish bailiff works under the district court's jurisdiction in his or her own law office ${ }^{5}$. The basic responsibility of a bailiff is to execute court de-

1 See L. Leszczyński, Types of Application of Law and Decision Making Model, „Studia Iuridica Lublinensia" 2015, Vol. 24(2), DOI: https://doi.org/10.17951/sil.2015.24.2.27, pp. 27-47.

2 Ibidem, p. 27.

3 The detailed list of enforcement bodies in administrative enforcement proceedings is presented in Articles 19 and 20 of the Act of 17 June 1966 on Administrative Proceedings in Administration (Journal of Laws 1966, No. 24, item 151 as amended).

4 We should point to these cases where a party is the Treasury or a public administration body which are also subject to judicial enforcement. This pertains mostly to these situations where public law claims are the object of enforcement (financial penalties or enforcement cases handed over to a court bailiff following the so-called concurrence of judicial and administrative enforcement).

5 Currently, the status of a court bailiff is regulated in Article 2 section 1 of the Act of 22 March 2018 on Court Bailiffs (Journal of Laws 2018, item 771 as amended): "A bailiff is a public officer operating at a district court", and in Article 3 section 1: "A bailiff is a public authority body who performs actions in enforcement proceedings and proceedings to secure claims". 
cisions: in pecuniary and non-pecuniary claims, in securing claims, bank accounts, inheritances, in making inventory lists, serving in court orders and recording the factual state of belongings ${ }^{6}$.

Judicial enforcement proceedings, as a part of law application, are a continuation to the right of access to court and supplement the decision-making process in the procedural, theoretical and philosophical dimensions. This stage is characterized by efficiency, effectiveness and reliability. These three values are clearly manifested in the Judicial Enforcement $\mathrm{Law}^{7}$. As a result, the new policy of enforcement law is developing, and it influences the bailiffs' work and imposes the necessity to respect the axiological conditions of law ${ }^{8}$.

It cannot be overlooked that the recent changes in enforcement law are strongly connected with introducing the general clauses referring to "the public interest" and "the interest of justice" which equally contribute to a bailiff's work and the application of enforcement law in general.

Since 1 January 2019, Poland has introduced two new Acts in judicial enforcement law ${ }^{10}$. One of the Acts refers to court bailiffs ${ }^{11}$ and the other Act is connected with the financial system of judicial enforcement law ${ }^{12}$.

It is necessary to point out the fact that even the smallest shift in law influences the axiological foundation. In accordance with the concept of axiological changes in law - an idea that has been discussed many times in theory of law ${ }^{13}$ - the notable variations in the whole system of Polish judicial enforcement have completely al-

${ }^{6}$ See Articles 3 and 4 of the Court Bailiff Act.

7 See, especially, Article 1 section 1 (5) of the Court Bailiff Act. The Act specifies: “[...] 5) the rules of supervision over bailiffs and bailiff self-government, taking into account the need to ensure that the tasks of the state with respect to efficient, effective and reliable judicial enforcement are duly fulfilled".

${ }^{8}$ More on axiological issues in law, see T. Barankiewicz, Aksjologiczna problematyka prawa, „Roczniki Nauk Prawnych” 2004, Vol. 14(1), pp. 45-58.

9 See Article 2 section 3 of the Court Bailiff Act: "While fulfilling his or her tasks, a bailiff is guided by the interest of justice and the public interest".

${ }^{10}$ Before 2019 in the Polish legal system there was only one act regulating judicial enforcement law. See Act of 29 August 1997 on Court Bailiffs and Enforcement (Journal of Laws 1997, No. 133, item 882 as amended).

11 See Act of 22 March 2018 on Court Bailiffs.

${ }^{12}$ See Act of 28 February 2018 on Enforcement Costs (Journal of Laws 2018, item 770 as amended).

${ }^{13}$ General reflections on the axiological basis in law and on its changes are presented by K. Pałecki (O aksjologicznych zmianach w prawie. Referat otwierajacy obrady XIII Zjazdu Katedr Teorii i Filozofii Prawa, [in:] Zmiany spoleczne a zmiany w prawie. Aksjologia, konstytucja, integracja europejska, red. L. Leszczyński, Lublin 1999, p. 18). As the author notes: "Nevertheless, in the law application process this official axiological basis has undergone quite a far-reaching transformation with respect to the composition, contents and hierarchy of importance - the transformation connected with interpretation made for the purposes of taking specific legal decisions". 
tered the axiological basis. This can mean axiological changes at the core of every decision made by a bailiff ${ }^{14}$. It can also be reflected in the way this branch of law is going to be perceived by people whom the law serves.

\section{GENERAL CLAUSES AS THE AXIOLOGICAL BASIS OF JUDICIAL ENFORCEMENT LAW. THE PUBLIC INTEREST VS THE INTEREST OF JUSTICE}

The idea of a general clause is a theoretical one and from this point of view it is mainly analyzed in the law doctrine ${ }^{15}$. The lack of a normative definition in the Polish legal sources does not preclude the use of this term in the law application process (particularly in the process of operative interpretation).

In the legal doctrine, a general clause is defined as "a normative construction (included in the text of a legal act) by which the legislator »communicates « with a recipient of norms in order to apply extra-legal criteria into any legal decision or law-obeying behaviour" 16 .

In the law application process, the term of a general clause refers to such ideas as: good manners, good intentions, justness, public interest, civic interest. In private law, the clauses are significantly noticeable in civil law ${ }^{17}$, where construction of abuse of law is the most frequently referred to. In public law, an example of applying general clauses is administrative law with Article 7 of the Administrative Procedure $\mathrm{Code}^{18}$. The present legal policy proves that judicial enforcement law is becoming more and more public ${ }^{19}$. The new Acts on judicial enforcement with

14 Ibidem, p. 19.

${ }^{15}$ General clauses are discussed the most extensively in theoretical law literature by L. Leszczyński who has analyzed this issue many times. See L. Leszczyński, Generalne klauzule odsytajace w stosowaniu prawa, Lublin 1986; idem, Tworzenie generalnych klauzul odsyłajacych, Lublin 2000; idem, Generalne klauzule odsyłajace - ujęcie teoretycznoprawne, „Annales UMCS sectio G (Ius)" 2016, Vol. 63(2), DOI: https://doi.org/10.17951/g.2016.63.2.11, pp. 11-26.

${ }^{16}$ See idem, Generalne klauzule odsyłające - ujęcie..., p. 13.

17 See Article 5 of the Act of 23 April 1964 - Civil Code (Journal of Laws 1964, No. 16, item 93 as amended): "One's right cannot be exercised in a way contrary to the socio-economic purpose of this right or the principles of community life. Such an act or omission of an entitled person is not regarded as execution of a right and is not protected".

18 See Article 7 of the Act of 14 June 1960 - Administrative Procedure Code (Journal of Laws 1960, No. 30, item 168 as amended): "In the course of the proceedings the public administration bodies protect the rule of law and undertake all actions necessary for clarification of the facts in detail and for dealing with the case, ex officio or at the parties' request, taking into consideration the public interest and the legitimate interests of citizens".

${ }^{19}$ M. Safjan directly points to the advancing process of private law "publicization". As he emphasizes: "A phenomenon sometimes referred to as publicization of private law has been noted for almost 100 years as a process of departing from the classical civil law, the basic ideas of which 
a bailiff's position itself and an enforcement fee are the elements which justify this opinion. It is also supported by the introduction of a general clause in the process of law application.

Since January 2019 in the existing Bailiff Act we can find clauses such as "the public interest" and "the interest of justice" which are completely new components to the Polish law enforcement system. The legislator introduced a direct reference to general clauses in Article 2 section 2 of the Bailiff Act $^{20}$. They serve as guideposts for a bailiff in his or her actions. The legislator imposed on bailiffs the responsibility to implement these clauses in the application of law.

A reference to a general clause could be included in the text of a decision (e.g. in a response to a complaint where a bailiff refers directly to these clauses as validation of his or her actions).

Will bailiffs refer to these clauses in writing (they could if they wanted to refer to them in any formal decision - documentation), or will they treat them more as mental guidelines? This will turn out in the course of practice only after some time.

The general clauses are not restricted only to a bailiff as the main enforcement body. The court itself can also use them in the process of law application. Such references can be found in court orders, but also in written recommendations concerning bailiffs and their actions directly ${ }^{21}$. To conclude, if we want to apply and interpret judicial enforcement law, it is impossible not to look at both clauses I mentioned and the values carried by them at every stage of the application process.

Theory of law presents various perspectives on the clause of public interest ${ }^{22}$. In general, one can distinguish three different concepts describing the relations

have been expressed in great codifications of the $19^{\text {th }}$ century. As it is noted, departure from these guidelines is demonstrated in the growing interference of the public factor in the sphere which was reserved earlier only for autonomous behaviour of individuals, in the regular restriction of the area where the private law method is applied to the benefit of public law regulations, that is taking out certain segments from the sphere of private law, the increasingly visible infiltration of community interest (public interest) in the area of the relations which were traditionally left exclusively to the parties, but also in the growing dispersion of institutions and solutions (a phenomenon of private law stratification), depending on the narrowly expressed purposes and functions of particular regulations" (M. Safjan, Pojęcie i systematyka prawa prywatnego, [in:] System Prawa Prywatnego, t. 1: Prawo cywilne-czesść ogólna, red. M. Safjan, Warszawa 2012, pp. 49-50).

20 "While fulfilling his or her tasks, a bailiff is guided by the interest of justice and the public interest".

${ }^{21}$ See Article $759 \S 2$ of the Act of 17 November 1964 - Civil Procedure Code (Journal of Laws 1964, No. 43, item 296 as amended): "The Court issues orders to a bailiff ex officio to ensure proper execution and removes infringements noticed. Legal opinions expressed by the court in the orders issued are binding on the bailiff".

${ }^{22}$ See A. Żurawik, ,Interes publiczny”, , ,interes społeczny” " ,, interes społecznie uzasadniony”, „Ruch Prawniczy, Ekonomiczny i Socjologiczny” 2013, nr 2, p. 60 ff. and the literature cited therein. Cf. A. Kalisz, Klauzula moralności (publicznej) w prawie polskim i europejskim jako przykład regulacyjnej, ochronnej oraz innowacyjnej funkcji państwa, „Principia” 2013, t. 57, passim. 
between public interest and interest of an individual ${ }^{23}$. The first of these concepts presents public interest as superior to interest of an individual ${ }^{24}$. In the second approach (common interest) $)^{25}$ the interest of every single individual together with the interest of minorities are highlighted. The third concept takes into account both public interest and interest of an individual, but it focuses on values that these two have in common ${ }^{26}$. These values can form the basis of the decision-making process.

The public interest clause has the widest implementation in public law ${ }^{27}$ where the broadly understood state interest plays the leading role (e.g. in administrative, tax, constitutional law $)^{28}$. There is an increasing number of theoretical views which argue that neither public interest nor interest of an individual is superior to each other. They coexist and, depending on the case character, can be used in law ${ }^{29}$.

The "new" enforcement law introduces new roles to definitions of such concepts as court bailiff, enforcement fee or court and administrative supervision. In this way, a public enforcement officer is obligated by law to apply this clause by "his or her service" while taking actions. Additionally, the construction of an enforcement fee as a public-law fee and re-defined administrative and court supervision (Minister of Justice, the Head of a District Court, local enforcement authorities) are attributed to changes in enforcement law which make it more public ${ }^{30}$.

The main task of public interest is to protect "public good" in order to guarantee respect for social values accepted by the whole community. This can mean protection of other parties not directly engaged in the enforcement procedure. For

${ }^{23}$ A. Żurawik, op. cit., p. 60.

${ }^{24}$ Ibidem.

25 Ibidem.

26 Ibidem.

${ }^{27}$ See E. Komierzyńska, M. Zdyb, Klauzula interesu publicznego $w$ działaniach administracji publicznej, „Annales UMCS sectio G (Ius)” 2016, Vol. 63(2), DOI: https://doi.org/10.17951/g.2016.63.2.161, p. 164.

28 Wprowadzenie do nauk prawnych. Leksykon tematyczny, red. A. Bator, Warszawa 2016, p. 206: "This law serves the interests of the state and of self-government legal persons (public interest); the legal relations distinguished here are the relations of the subordinate type, that is they are based on the competence subordination relations and superiority (asymmetry) of legal subjects. In this law, the state is the initiator of actions".

${ }^{29}$ See A. Żurawik, op. cit., p. $60 \mathrm{ff}$. In the author's opinion: "Currently, there is not much doubt that public interest cannot be arbitrarily deemed superior to individual interest, because the two interests must be balanced in every situation". The presented opinion is justified with the views in the doctrine and the judicial practice of the Supreme Court and the Constitutional Tribunal. Similar views are presented by Z.R. Kmiecik, M. Grzeszczuk and E. Streit-Browarna (Klauzula generalna interesu spotecznego $w$ postepowaniu administracyjnym, sq̨dowoadministracyjnym oraz egzekucyjnym w administracji, „Annales UMCS sectio G (Ius)” 2016, Vol. 63(2), DOI: https://doi. org/10.17951/g.2016.63.2.209, p. 213).

${ }^{30}$ See comment to Article 1 of the Court Bailiff Act in: Ustawa o komornikach sadowych. Komentarz, red. R. Reiwer, Warszawa 2019, Legalis, passim. 
example, when a company that is a debtor has to close down and reduce the staff as a consequence of too oppressive enforcement actions, one must consider the interest of the staff as a public good and adjust enforcement actions in order not to hurt anyone.

Not only public interest but also the bailiff's interest, the state's interest and the interest of a party concerned are defined by a Court Bailiff Act. Moreover, they all represent public interest to the same extent. Therefore, there is no need to fix the hierarchy because each of them respects the idea of protecting "public good".

An enforcement officer must choose what action to take that is effective and, at the same time, safeguards public interest. I want to point out here that there is a ban on seizure exceeding the claim in the Civil Procedure Code in Article 799 $\S 1$ sentence 4 ("An enforcement authority applies such a mode of execution that is the least troublesome for the debtor") because if it is too oppressive for the debtor it does not pursue the intentions of general clauses.

The second clause I am going to present in this article is "the interest of justice" clause. It is interesting from the theoretical and philosophical point of view, but it also raises a number of questions concerning the practice. They may be hard to answer, probably because there is not much practice developed in this new judicial enforcement law.

In order to understand the changes better and help answer the questions, we can use knowledge and experience from other branches of law. A great example here can be case-law developed on the basis of the Polish Criminal Procedure Code that is Article 37: "The Supreme Court may, upon the motion of the court having jurisdiction over the case, refer the case to be heard by another court of the same level if this is required by the interest of justice". In these cases court in decision refers to the interest of justice in order to guarantee the rightfulness of the proceedings ${ }^{31}$.

To put the clause into practice we must consider a few articles. In particular, Article 2.3 of the Court Bailiff Act which provides that "While taking action, a bailiff follows the interest of justice [...]".

When we look at the enforcement procedure as an integral part of the law application model with all its stages, we can associate this clause with the right to a case in court and initiating enforcement proceedings as a consequence. These actions must serve their purpose, namely to effectively execute enforceable titles.

${ }^{31}$ See extensive discussion on the role of the interest of justice clause in the criminal procedure: B. Dudzik, Generalne klauzule odsyłajace w procesie karnym na przyktadzie dobra wymiaru sprawiedliwości (uwagi na tle art. 37 k.p.k.), „Annales UMCS sectio G (Ius)” 2016, Vol. 63(2), DOI: https://doi.org/10.17951/g.2016.63.2.279, pp. 279-289 and the literature cited therein. 


\section{COURT BAILIFF'S DISCRETION IN THE LAW APPLICATION PROCESS. THE NEW RESEARCH PERSPECTIVE}

Functioning of a court bailiff in the broadly understood justice concept is strongly connected with his or her place in judicial law application ${ }^{32}$.

Reconstruction of the entire law application model (no matter whether judicial or administrative) puts it in the final stage of the process leading to concrete-individual norm realization, one that is pre-specified in enforceable titles (law application decision - judgement, decision, payment order).

The actions taken by enforcement officers in the decision-making process are of various character. They can be declarative steps, technical activities or research work $^{33}$. The majority of enforcement actions are of declarative character (settlements, regulations or seizures), which means they automatically add the discretion element into bailiffs' work.

Let us leave the detailed considerations on the discretion term and focus on the fact that discretion, its relationship with judicial discretion and its limitation are the major elements in the legal order according to Polish and foreign legal doctrine ${ }^{34}$.

For the purpose of this article, the discretion term is connected by the author with a specified range of discretion for the executive body applying law. In the case of judicial discretion, the term is wide and "involves the right to make decisions which are not directly stated in the legal text, wherewith it is of no importance what law application stage these decisions concern" 35 . I do not, however, understand this term as a legal body's limitless freedom to decide ${ }^{36}$.

A court bailiff's discretion, understood in such a way, is inseparably associated in the law application process with the model of practical, that is operative,

${ }^{32}$ See L. Leszczyński, Model decyzyjny procesu stosowania prawa, [in:] A. Korybski, L. Leszczyński, Stanowienie i stosowanie prawa. Elementy teorii, Warszawa 2015, pp. 147-148.

33 See A. Marciniak, Sadowe postępowanie egzekucyjne, Warszawa 2013, p. 126.

${ }^{34}$ See N. Isaacs, The limits of judicial discretion, "Yale Law Journal"1923, Vol. 32, https:// digitalcommons.law.yale.edu/ylj/vol32/iss4/2 [access: 29.12.2019]; R.M. Dworkin, The Model of Rules, https://digitalcommons.law.yale.edu/fss_papers/3609 [access: 29.12.2019]; J. Raz, Legal Principles and the Limits of Law, "Yale Law Journal" 1972, Vol. 81, https:/digitalcommons.law. yale.edu/ylj/vol81/iss5/2 [access: 29.12.2019]; B. Wojciechowski, Dyskrecjonalność sędziowska. Studium teoretycznoprawne, Toruń 2004; W. Staśkiewicz, T. Stawecki, Dyskrecjonalność w prawie, Warszawa 2010; Dyskrecjonalna władza sędziego. Zagadnienia teorii i praktyki, red. M. Dębiński, R. Pelewicz, T. Rakoczy, Tarnobrzeg 2012; A. Kotowski, Dyskrecjonalność władzy administracyjnej - próba nowego ujęcia, „Krytyka Prawa” 2014, t. 6, pp. 51-77.

${ }_{35}$ See Z. Czarnik, Prawotwórcza rola sq̨du a dyskrecjonalność sędziowska, [in:] Dyskrecjonalna władza sędziego ..., p. 16.

${ }^{36}$ In my opinion, connecting such decision-making discretion with the two basic elements, described by A. Kotowski (op. cit., p. 64) as "unconscious pre-comprehension" and "conscious overdetermination", is a right supplement to this meaning. 
interpretation of law, which is connected with the process leading to making and issuing the final decision ${ }^{37}$. In agreement with J. Wróblewski: "The operative interpretation can be described as a practice of law-applying bodies" 38 . This author views it also as an indispensable element of the law application process which influences the content of a decision made ${ }^{39}$. From the perspective of the judicial enforcement proceedings (especially a court bailiff as a law-applying body), according to L. Leszczyński ${ }^{40}$, the two features typical of the operative model of law interpretation will be particularly useful.

Firstly, the focus is on discretion - the context of interpretation related to decision-making ${ }^{41}$ - which means that it is an "element of the decision-making process" ${ }^{42}$. The scope of discretion in the process of enforcement of a judicial decision is determined by a list of actions (enforcement actions ${ }^{43}$ ) taken by a court bailiff. It means that specific enforcement actions (especially decision-making actions ${ }^{44}$ ) are preceded by the process of looking for the legal basis of such an action. Other consequences of this reasoning are no longer the main concern of the operating subject (a court bailiff).

Secondly, the focus is on "situationality" that is the element related to the interpretational situation, determined primarily by parallel establishment of the factual state ${ }^{45}$. Situationality in this sense significantly influences the borders of operative reasoning, the aim of which is to interpret this fragment of a norm (the normative basis of a decision) which is connected with the factual state ${ }^{46}$ (at this stage with the enforcement law-based factual state). This is also important from

37 The model of operative interpretation of law has been discussed many times in the Polish theoretical law literature. See L. Leszczyński, Wykładnia operatywna (podstawowe właściwości), „Państwo i Prawo” 2009, z. 6, pp. 11-23; idem, Wyktadnia prawa-model ogólny, [in:] A. Kalisz, L. Leszczyński, B. Liżewski, Wyktadnia prawa. Model ogólny a perspektywa Europejskiej Konwencji Praw Człowieka i Prawa Unii Europejskiej, Lublin 2011, pp. 13-31; A. Szot, L. Leszczyński, Wyktadnia operatywna prawa. Perspektywa teoretyczna i dogmatyczna, Torun 2017; M. Zieliński, Wybrane zagadnienia wyktadni prawa, „Państwo i Prawo” 2009, z. 6, pp. 3-10; J. Wróblewski, An Outline of a General Theory of Legal interpretation and constitutional interpretation, „Acta Universitatis Lodziensis. Folia Iuridica" 1987, Vol. 32, pp. 42-55.

38 See J. Wróblewski, Rozumienie prawa i jego wyktadnia, Warszawa 1990, p. 74.

39 See idem, Sadowe stosowanie prawa, Warszawa 1988, p. 112.

40 See L. Leszczyński, Wyktadnia prawa ..., pp. 15-16.

${ }^{41}$ See idem, Wyktadnia operatywna ..., p. 13.

${ }^{42}$ See J. Wróblewski, Sadowe stosowanie ..., p. 112. It should be noticed that the explanation of meanings of doubtful provisions is not the most important in this type of interpretation, but this process is not overlooked in this type of reasoning, either.

${ }^{43}$ More on this subject A. Marciniak, op. cit., p. $124 \mathrm{ff}$.

${ }^{44}$ Examples can be court bailiff's actions in the form of a decision on suspension or discontinuation of enforcement proceedings, e.g. Articles 818, 819, 824 and 825 of the Civil Procedure Code.

${ }^{45}$ See L. Leszczyński, Wykładnia prawa ..., p. 15 ff.

${ }^{46}$ Ibidem, p. 16. 
the perspective of speed as one of the basic values of the judicial enforcement law (there is no need to reconstruct the entire enforcement norm) ${ }^{47}$.

My practice in the judicial enforcement proceedings and the analysis of justification of the selected judgements of the Supreme Court in enforcement cases convinces me to apply the rule omnia sunt interpretand $a^{48}$ at the reconstruction of an enforcement norm to be applied, and hence to depart from the clarification approach to the interpretation defined by a legal maxim clara non sunt interpretanda. For accomplishment of the purpose and function of judicial enforcement, the linguistic directives of interpretation turn out to be insufficient for application in the process of reconstruction of a norm. In my opinion, the reasoning should be supplemented with the conclusions drawn from the extralinguistic rules, including in particular the results of systemic and extrasystemic directives (functional, purposive and axiological) to implement fully the principle of omnia sunt interpretanda in the operative interpretation of enforcement law ${ }^{49}$.

With such assumptions, one can eventually ask a question: Does a court bailiff, like a judge or an administrative body, have a specified range of discretion in the law application process? In general, the answer should be positive, especially in light of the new axiological basis. Discretion of an enforcement body becomes a real tool to settle complicated enforcement cases, which should be conducive to a good decision ${ }^{50}$.

In the course of action, a bailiff faces many decisions and these made by him or her must be good. What does it mean - a good decision? ${ }^{51}$ Article 1 of the Court Bailiff Act indicates the factors which make a decision good. They are efficiency, effectiveness, reliability ${ }^{52}$.

In Poland, bailiffs' actions are always supervised by the court. This doesn't mean that the court directly controls every step of a bailiff. He or she acts upon his or her own decisions which must lead to effective execution of an enforceable title. So, what about bailiffs' discretion? Nowadays, a bailiff can decide what kind

47 Limitation of the scope of interpretation (to a fragment of an enforcement norm) helps coping with protraction of enforcement proceedings. Cf. idem, Wyktadnia operatywna .., p. $15 \mathrm{ff}$.

48 The principle of omnia sunt interpretanda is increasingly applied also in theoretical law literature concerning interpretation. See M. Zieliński, Wykładnia prawa. Zasady, reguły, wskazówki, Warszawa 2008, passim. Cf. M. Zieliński, M. Zirk-Sadowski, Klaryfikacyjność i derywacyjność w integrowaniu polskich teorii wyktadni, „Ruch Prawniczy, Ekonomiczny i Socjologiczny” 2011, nr 2; L. Leszczyński, Wyktadnia prawa..., p. 22.

49 See A. Korybski, L. Leszczyński, op. cit., p. 154.

${ }^{50}$ On a good decision in actions of the public administration, see W. Dziedziak, O dyskrecjonalności administracji publicznej w procesach stosowania prawa, „Studia Iuridica Lublinensia” 2017, Vol. 26(3), DOI: https://doi.org/10.17951/sil.2017.26.3.25, 2017, pp. 25-45.

${ }^{51}$ See ibidem, p. 35: "An official should take good decisions, and a decision is an act of choice, intellect and will. This decision should serve the good of a human being".

${ }^{52}$ See Article 1 (5) of the Court Bailiff Act. See also T. Barankiewicz, op. cit. 
of actions should be taken against a debtor, but he or she must remember that all steps taken cannot be excessively harmful to the debtor, and they have to comply with the basic rules, like the clauses I have discussed before.

I believe two areas of bailiff's discretion can be suggested. The first one is the area of wide discretion because an enforcement officer decides which steps to take dealing with each individual case.

As far as I am concerned, bailiff's discretion depends on the nature of a case. There are a number of actions taken and decided by a bailiff. They can vary depending on the character of the proceedings. They are different for pecuniary issues (however, a "mode of execution that is the least troublesome for the debtor must be always followed" - Article $799 \S 1$ sentence 4 of the Civil Procedure Code) and non-pecuniary issues, as they can entail different enforcement steps. It is determined by the executive body whether a case should be dropped when ineffectual due to lack of assets (here we deal with estimations, wealth rate - determining such elements as enforcement fees, case costs and debtor's wealth). When enforcement costs exceed debtor's possessions, the case should be dropped in accordance with Article $824 \S 1$ item 3 of the Civil Procedure Code.

The other area is when discretion is completely limited simply by direct court orders - Article $759 \S 2$ of the Civil Procedure Code ("The court issues ex officio orders to a bailiff to ensure proper execution and removes infringements noticed. Legal opinions given by the court in the orders issued are binding on the bailiff") ${ }^{53}$.

There should be no problem with distinguishing between these two areas of enforcement officer's discretion, but let's ask ourselves: Is there anything in between? The answer may be the cases that get complicated during the course of action. A situation, for example, when a debtor hides his or her real assets (like a car, cash, other material goods). In such cases, bailiff's discretion is not limited but changed. Bailiff is forced to adjust his or her actions and, at the same time, he or she must turn to a creditor, explain all new facts to him or her and cooperate more strongly with him or her. The enforcement officer's actions depend now on the creditor's decisions. Bailiff still operates within his or her discretion, however, in "new" conditions.

\section{CONCLUSION}

In my opinion, the scope of bailiff's discretion is really wide, but let's remember that it is completely different from judicial discretion. Whereas judges appeal to extra legal factors (like social norms, moral rules) in their decisions, refer to general clauses, legal principles and precedential practice, bailiffs rather use them

53 There are also situations when bailiff's discretion is limited not by the court order but the law. An example here is the fact of debtor's death which forces the bailiff to suspend his or her proceedings. 
as mental indicators ${ }^{54}$. Judges and bailiffs operate at different stages of law application. Bailiff's work is usually seen as the final stage, however, this position does not deprive him or her of discretion. I personally feel that bailiff's discretion gives a lot of freedom in his or her actions, but we must also remember that a bailiff is not a freelancer but an official. All actions taken by him or her are laid down in law.

Currently, bailiff's discretion is supplemented with the clauses of "public interest" and "justice interest" and surely they contribute to the discretion limitations. The introduction of these two clauses has completely changed the Polish axiology of judicial enforcement law and it will take time to see how all these will influence bailiff's discretion and if its limitations will become wider.

\section{REFERENCES}

\section{Literature}

Barankiewicz T., Aksjologiczna problematyka prawa, „Roczniki Nauk Prawnych” 2004, Vol. 14(1). Czarnik Z., Prawotwórcza rola sądu a dyskrecjonalność sędziowska, [in:] Dyskrecjonalna władza sędziego. Zagadnienia teorii i praktyki, red. M. Dębiński, R. Pelewicz, T. Rakoczy, Tarnobrzeg 2012.

Dudzik B., Generalne klauzule odsyłajace w procesie karnym na przykładzie dobra wymiaru sprawiedliwości (uwagi na tle art. 37 k.p.k.), „Annales UMCS sectio G (Ius)” 2016, Vol. 63(2),

DOI: https://doi.org/10.17951/g.2016.63.2.279.

Dworkin R.M., The Model of Rules, https://digitalcommons.law.yale.edu/fss_papers/3609 [access: 29.12.2019].

Dyskrecjonalna władza sędziego. Zagadnienia teorii i praktyki, red. M. Dębiński, R. Pelewicz, T. Rakoczy, Tarnobrzeg 2012.

Dziedziak W., O dyskrecjonalności administracji publicznej w procesach stosowania prawa, „Studia Iuridica Lublinensia” 2017, Vol. 26(3), DOI: https://doi.org/10.17951/sil.2017.26.3.25.

Isaacs N., The limits of judicial discretion, "Yale Law Journal"1923, Vol. 32, https://digitalcommons. law.yale.edu/ylj/vol32/iss4/2 [access: 29.12.2019].

Kalisz A., Klauzula moralności (publicznej) w prawie polskim i europejskim jako przykład regulacyjnej, ochronnej oraz innowacyjnej funkcji państwa, „Principia” 2013, t. 57.

Kmiecik Z.R.,Grzeszczuk M., Streit-Browarna E., Klauzula generalna interesu społecznego w postępowaniu administracyjnym, sądowoadministracyjnym oraz egzekucyjnym $w$ administracji, „Annales UMCS sectio G (Ius)" 2016, Vol. 63(2), DOI: https://doi.org/10.17951/g.2016.63.2.209.

Komierzyńska E., Zdyb M., Klauzula interesu publicznego w działaniach administracji publicznej, „Annales UMCS sectio G (Ius)" 2016, Vol. 63(2), DOI: https://doi.org/10.17951/g.2016.63.2.161.

Korybski A., Leszczyński L., Stanowienie i stosowanie prawa. Elementy teorii, Warszawa 2015.

Kotowski A., Dyskrecjonalność władzy administracyjnej - próba nowego ujęcia, „Krytyka Prawa” 2014, t. 6.

${ }^{54}$ On the "opening" of the legal system to extralegal criteria, see L. Leszczyński, Zagadnienia teorii stosowania prawa. Doktryna i tezy orzecznictwa, Kraków 2004, p. 310 ff. 
Leszczyński L., Generalne klauzule odsyłające - ujęcie teoretycznoprawne, „Annales UMCS sectio G (Ius)" 2016, Vol. 63(2), DOI: https://doi.org/10.17951/g.2016.63.2.11.

Leszczyński L., Generalne klauzule odsyłające w stosowaniu prawa, Lublin 1986.

Leszczyński L., Model decyzyjny procesu stosowania prawa, [in:] A. Korybski, L. Leszczyński, Stanowienie i stosowanie prawa. Elementy teorii, Warszawa 2015.

Leszczyński L., Tworzenie generalnych klauzul odsyłających, Lublin 2000.

Leszczyński L., Types of Application of Law and Decision Making Model, „Studia Iuridica Lublinensia" 2015, Vol. 24(2), DOI: https://doi.org/10.17951/sil.2015.24.2.27.

Leszczyński L., Wykładnia operatywna (podstawowe właściwości), „Państwo i Prawo” 2009, z. 6.

Leszczyński L., Wykładnia prawa-model ogólny, [in:] A. Kalisz, L. Leszczyński, B. Liżewski, Wykładnia prawa. Model ogólny a perspektywa Europejskiej Konwencji Praw Człowieka i Prawa Unii Europejskiej, Lublin 2011.

Leszczyński L., Zagadnienia teorii stosowania prawa. Doktryna i tezy orzecznictwa, Kraków 2004. Marciniak A., Sadowe postępowanie egzekucyjne, Warszawa 2013.

Pałecki K., O aksjologicznych zmianach w prawie. Referat otwierajacy obrady XIII Zjazdu Katedr Teorii i Filozofii Prawa, [in:] Zmiany społeczne a zmiany w prawie. Aksjologia, konstytucja, integracja europejska, red. L. Leszczyński, Lublin 1999.

Raz J., Legal Principles and the Limits of Law, "Yale Law Journal” 1972, Vol. 81, https://digitalcommons.law.yale.edu/ylj/vol81/iss5/2 [access: 29.12.2019].

Safjan M., Pojęcie i systematyka prawa prywatnego, [in:] System Prawa Prywatnego, t. 1: Prawo cywilne - część ogólna, red. M. Safjan, Warszawa 2012.

Ustawa o komornikach sadowych. Komentarz, red. R. Reiwer, Warszawa 2019, Legalis.

Staśkiewicz W., Stawecki T., Dyskrecjonalność w prawie, Warszawa 2010.

Szot A., Leszczyński L., Wyktadnia operatywna prawa. Perspektywa teoretyczna i dogmatyczna, Torun 2017.

Wojciechowski B., Dyskrecjonalność sędziowska. Studium teoretycznoprawne, Torun 2004.

Wprowadzenie do nauk prawnych. Leksykon tematyczny, red. A. Bator, Warszawa 2016.

Wróblewski J., An Outline of a General Theory of Legal interpretation and constitutional interpretation, „Acta Universitatis Lodziensis. Folia Iuridica” 1987, Vol. 32.

Wróblewski J., Rozumienie prawa i jego wykładnia, Warszawa 1990.

Wróblewski J., Sadowe stosowanie prawa, Warszawa 1988.

Zieliński M., Wybrane zagadnienia wyktadni prawa, „Państwo i Prawo” 2009, z. 6.

Zieliński M., Wykładnia prawa. Zasady, reguty, wskazówki, Warszawa 2008.

Zieliński M., Zirk-Sadowski M., Klaryfikacyjność i derywacyjność w integrowaniu polskich teorii wyktadni, „Ruch Prawniczy, Ekonomiczny i Socjologiczny” 2011, nr 2.

Żurawik A., ,,Interes publiczny”, ,, interes społeczny” i ,,interes społecznie uzasadniony”, „Ruch Prawniczy, Ekonomiczny i Socjologiczny" 2013, nr 2.

\section{Legal acts}

Act of 14 June 1960 - Administrative Procedure Code (Journal of Laws 1960, No. 30, item 168 as amended).

Act of 23 April 1964 - Civil Code (Journal of Laws 1964, No. 16, item 93 as amended).

Act of 17 November 1964 - Civil Procedure Code (Journal of Laws 1964, No. 43, item 296 as amended).

Act of 17 June 1966 on Administrative Proceedings in Administration (Journal of Laws 1966, No. 24, item 151 as amended). 
Pobrane z czasopisma Studia Iuridica Lublinensia http://studiaiuridica.umes.pl

Data: 26/04/2023 03:02:04

Act of 29 August 1997 on Court Bailiffs and Enforcement (Journal of Laws 1997, No. 133, item

882 as amended).

Act of 28 February 2018 on Enforcement Costs (Journal of Laws 2018, item 770 as amended).

Act of 22 March 2018 on Court Bailiffs (Journal of Laws 2018, item 771 as amended).

\section{STRESZCZENIE}

W artykule autor skoncentrował się na trzech zagadnieniach teoretyczno-filozoficznych sądowego prawa egzekucyjnego w Polsce związanych z wejściem w życie z dniem 1 stycznia 2019 r. nowych ustaw komorniczych. W pierwszej kolejności przedstawiono sądowe postępowanie egzekucyjne jako element procesu stosowania prawa. Wymiar aksjologiczny tego prawa, miejsce i funkcja komornika sądowego w procesie stosowania prawa oraz wprowadzenie generalnych klauzul odsyłających w zestawieniu z podstawowymi wartościami sądowego prawa egzekucyjnego w postaci skuteczności, sprawności i rzetelności kształtują nowy obraz sądowego prawa egzekucyjnego. Po drugie, podjęto problematykę generalnej klauzuli odsyłającej jako „nośnika” kryteriów pozaprawnych, która w nowym prawie komorniczym zajmuje ważne miejsce w procesie stosowania prawa egzekucyjnego. Szczególna w tym rola klauzul „interesu publicznego” i „dobra wymiaru sprawiedliwości” jako konstrukcji normatywnej wprowadzonej przez ustawodawcę do egzekucji sądowej. Po trzecie, podjęto próbę odpowiedzi na pytanie o obecność oraz ewentualną granicę dyskrecjonalności (swobody decyzyjnej) komornika sądowego w warunkach nowej aksjologii prawa egzekucyjnego, a w szczególności formułowanie tego zagadnienia w procesie operatywnej wykładni prawa dokonywanej przez komornika sądowego.

Słowa kluczowe: aksjologia prawa; sądowe prawo egzekucyjne; proces stosowania prawa; klauzula generalna; interes publiczny; dobro wymiaru sprawiedliwości; dyskrecjonalność komornika 